\title{
Human Albumin Antibody Measurement
}

National Cancer Institute

\section{Source}

National Cancer Institute. Human Albumin Antibody Measurement. NCI Thesaurus. Code C103405.

The determination of the amount of the human albumin antibody in a sample. 